VOX PATRUM 29 (2009) t. 53-54

Monika OŻÓG

(Opole, UO)

\title{
CEREMONIE ZAWARCIA MAŁŻEŃSTWA W RELACJI ŚW. JANA CHRYZOSTOMA
}

„Małżeństwo uważane jest za dzieło godne uszanowania zarówno u nas, jak też i u pogan; i w rzeczywistości jest ono zaszczytne, lecz podczas zawierania małżeństw czyni się wiele rzeczy śmiesznych, jak o tym zaraz usłyszycie". Ceremonia zawierania małżeństwa przez chrześcijan w czasach Jana Chryzostoma była obchodzona według ówcześnie obowiązujących norm i zwyczajów społecznych, wywodzących się z kultury pogańskiej, a także z prawa rzymskiego ${ }^{2}$. W 2. poł. IV wieku nie funkcjonowała bowiem jeszcze wśród chrześcijan żadna własna ceremonia liturgiczna zawierania małżeństwa. Antiochia będąca pierwszym miejscem wielu mów i pism Chryzostoma, była miastem zdecydowanie wyróżniającym się na tle innych ówczesnych ośrod-

\footnotetext{
${ }^{1}$ Joannes Chrysostomus, In Epistolam I ad Corinthios hom. 12, 5, PG 61, 103B, thum. za M. Dmitruk, Obyczaje weselne i pogrzebowe chrześcijan w świetle duszpasterskiej działalności św. Jana Chryzostoma, VoxP 21 (2001) t. 40-41, 269.

${ }^{2}$ Por. L. Anné, La conclusion du mariage dans la tradition et le droit de l'Église Latine jusqu'au $V I^{e}$ siècle, EThL 12 (1955) 513-550; H. Insadowski, Rzymskie prawo matżeńskie a chrześcijaństwo, Lublin 1935, spec. 113-146 (Formy zawarcia małżeństwa); P. Jounel, La liturgie Romaine du mariage. Étapes de son élaboration, MD 50 (1957) 30-57; J.H. Dalmais, La liturgie du mariage dans les Églises orientales. Structure, histoire, signification, MD 50 (1957) 58-70; M. Righetti, Manuale di storia liturgica, IV, Milano 1959, 453-472 (Il rito nuziale pagano e cristiano); F. Małaczyński, Obrzędy sakramentu matżeństwa w rozwoju historycznym, RBL 14 (1961) z. 1-2, 53-57; K. Ritzer, Formen, Riten und religiöses Brauchtum der Eheschliessung in der christlichen Kirchen des ersten Jahrhunderts, Münster 1962; W. Plautz, Die Form der Eheschliessung im Alten Testament, ZAW 76 (1964) 298-318; R. Metz, Le rituel du mariage. Origine et évolution historique. Appendice I, w tegoż: La consécration des vierges dans l'Église Romaine. Étude d'histoire de la liturgie, Paris 1964, 363-410; K. Ritzer, Le mariage dans les Églises chrétiennes du I ${ }^{e r}$ au XI siècle, Paris 1970; L. Winniczuk, Ludzie, zwyczaje, obyczaje starożytnej Grecji i Rzymu, Warszawa 1983, 199-261 (W rodzinie greckiej i rzymskiej); A. Niebergall, Ehe und Eheschliessung in der Bibel und in der Geschichte der alten Kirche, Marburg 1985; G.L. Falchi, La legislazione imperiale circa i matrimoni misti fra Christiani ed Ebrei nel IV secolo, w: Atti del VII Convegno Internazionale dell'Accademia Romanistica Costantiniana dell'Università degli Studi di Perugia. Facolta di Jurisprudenza. VII Convegno Internazionale Napoli 1988, 203-211; G. Kadzioch, Il ministro del sacramento del matrimonio nella tradizione e nel diritto canonico latino e orientale, Roma 1997, 71-80; C. Delling, Eheschließung, RACh IV 719-731.
} 
ków. Przenikały się w niej różnorakie elementy kulturowe ${ }^{3}$, i to właśnie kultura była jej największą wartością ${ }^{4}$. Choć większość mieszkańców tego miasta nie była pochodzenia greckiego, to ośrodek ten miał charakter typowo helleński, podobnie jak i wspólnota chrześcijańska, która zaczęła się tam zakorzeniać i rozwijaćs. Podobny charakter kulturowy, choć już z większymi wpływami rzymskimi, miał Konstantynopol, stolica cesarstwa - drugie miejsce duszpasterskiej działalności Jana Chryzostoma.

Niniejszy temat, dotyczący obrzędów, jakie miały miejsce podczas ceremonii zawarcia małżeństwa, poruszany był przez Jana Chryzostoma wielokrotnie. W swoich pismach, generalnie krytykował i potępiał obyczaje weselne o charakterze pogańskim, bardzo ściśle związane z ceremonią zaślubin. Złotousty widział w nich przede wszystkim zagrożenie dla moralności chrześcijan. Rzecz jasna, nie znaczy to, iż był przeciwnikiem wszelkich ceremonii zawierania małżeństwa. W swoich mowach sygnalizował jedynie nadmierną wystawność, zapraszanie aktorów i teatralność muzyki oraz inne złe tradycyjne nawyki, które uwłaczały godności panny młodej i samego sakramentu małżeństwa, a także były źródłem wielu niemoralnych nadużyć. Zdawał sobie przy tym sprawę, że tak zarysowane przez niego stanowisko może być przyczyną postrzegania jego osoby jako zbyt zacofanej i konserwatywnej ${ }^{6}$, a nawet narazić go na śmieszność 7 .

${ }^{3}$ Por. G. Haddad, Aspects of Social Life in Antioch in the Hellenistic-Roman Period, Chicago 1949, 117.

${ }^{4}$ Por. J. Kollwitz, Antiochia am Orontes, RACh I 462. Na temat późnoantycznej Antiochii oraz m. in. instytucji małżeństwa u Chryzostoma, zob. P. Szczur, Problematyka społeczna w późnoantycznej Antiochii na podstawie nauczania homiletycznego Jana Chryzostoma, Lublin 2008, 293-361 (Małżeństwo i rodzina); P. Rentinck, La cura pastorale in Antiochia nel IV secolo, Roma 1970, 251-277 (Il matrimonio); Ritzer, Le mariage dans les Églises chrétiennes, s. 130-141; L. Dattrino, Il matrimonio nel pensiero di San Giovanni Crisostomo, Roma 2002, 49-58 (La celebrazione delle nozze).

${ }^{5}$ Por. G. Bardy, La question des langues dans l'Église ancienne, Paris 1948, 18.

${ }^{6}$ Por. In epistulam I ad Corinthios hom. 12, 6, PG 61, 104.

${ }^{7}$ Por. Joannes Chrysostomus, In illud: „Propter fornicationes unusquisque uxorem habeat” 2, PG 51, 210, tłum. S. Longosz: Widowiska teatralne zagrożeniem dla życia rodzinnego wedtug św. Jana Chryzostoma, w: Chrześcijanie a życie publiczne w Cesarstwie Rzymskim III-IV wieku, red. J. Śrutwa, Lublin 1988, s. 185: „Nie bezcześćmy godów weselnych przepychem diabelskim, ale tak jak to miało miejsce u ludzi w Kanie Galilejskiej, niech i teraz będzie praktykowane przez wstępujących w związek małżeński, aby mieli pośród siebie goszczącego Chrystusa. Powie ktoś: w jaki sposób tego dokonać? - Przez zaproszenie kapłanów. Powiedział bowiem; «Kto was przyjmuje, Mnie przyjmuje» (Mt 10, 40). Jeśli więc odpędzisz diabła, odrzucisz lubieżne piosenki i bezwstydne śpiewy, rozwiązłe tańce i brzydkie słownictwo, diabelski przepych, wrzawę i wyuzdany śmiech, i pozostałą ohydę, a wprowadzisz święte sługi Chrystusa, to Chrystus przez nich będzie obecny wraz ze swą Matką i braćmi [...]. Wiem, że niektórym zdaję się być zgryźliwy i przykry, gdy was do tego zachęcam j podcinam stary zwyczaj, ale nie troszczę się o to; nie tyle bowiem potrzebuję waszej łaski, ile pożytku, nie tyle oklasków i pochwał, ile zysku i roztropności. Niech mi nikt nie mówi, że jest to zwyczaj; gdzie się bowiem popełnia grzech, nie wspominaj zwyczaju, a gdzie się 
Analizując opisywane przez Chryzostoma obrzędy, możemy ceremonię zaślubin chrześcijan podzielić na kilka etapów ${ }^{8}$ :

1. Pierwsza $z$ nich rozpoczynała się rano. Wtedy w domu rodzinnym panny młodej, zgodnie z tradycją exdosis, narzeczona była powierzana przyszłemu mężowi.

2. Następnie odbywała się wystawna uczta weselna.

3. Wieczorem zbierał się orszak, który prowadził młodą parę do domu pana młodego.

4. Huczna celebracja uroczystości kończyła się w okazale udekorowanym girlandami domu męża. Ten przyjmował żonę i prowadził ją do swego łoża. Od tego momentu młodzi małżonkowie rozpoczynali nowe życie we wspólnocie, zapominając o wszystkich poprzednich związkach.

Niewątpliwie najważniejszy etap z punktu widzenia chrześcijan miał miejsce rano, kiedy małżonkowie deklarowali chęć bycia ze sobą. Od samego poranka narzeczona $\mathrm{w}$ stroju ślubnym oczekiwała przyszłego męża $\mathrm{W}$ swoim domu rodzinnym, gdzie zgodnie z ceremonią dextrarum coniunctio (symboliczne złączenie dłoni nowożeńców przez pronubę, często w obecności kapłana) $)^{9}$, oboje wyrażali chęć zawarcia małżeństwa. Możemy stwierdzić, że o ważności związku decydowała jedynie wzajemna ich zgoda. Układ małżeński zapisany w tabulae nuptiales lub matrimoniales, tworzący akt cywilny zawarcia związku, obowiązywał także i chrześcijan. Polegał on na głośnym odczytaniu formuły małżeńskiej w obecności świadków, deklarującej m.in. datę, wysokość posagu i cel zawieranego małżeństwa-zrodzenie potomstwa, powodując tym samym określony skutek prawny ${ }^{10}$. Potem zgodnie ze starym zwyczajem greckim, początkowo przez chrześcijan odrzucanym jako praktyka pogańska (Klemens Aleksandryjski, Minucjusz Feliks, Tertulian), a później od III wieku akceptowanym, następowała ceremonia koronowania nowożeńców ślubnymi wieńcami $\mathrm{z}$ kwiatów ${ }^{11}$. Panna młoda ubrana $\mathrm{w}$ białą pozbawioną

dzieją rzeczy złe, to choćby to był stary zwyczaj, usuń go, a gdzie nie ma zła, to choćby nie było zwyczaju, wprowadź go i przestrzegaj. Nic było zresztą takiego starego zwyczaju, by urządzać takie bezwstydne rzeczy, ale przekonasz się, że wprowadzono go jako nowość, gdy sobie przypomnisz, w jaki sposób Izaak pojmował za żonę Rebekę, a Jakub Rachelę".

${ }^{8}$ Por. Rentinck, La cura pastorale in Antiochia nel IV secolo, s. 257-258.

9 Por. B. Kötting, Dextrarum iunctio, RACh III 881-888; Insadowski, Rzymskie prawo matżeńskie, s. 137-138.

${ }^{10}$ Por. C. Tibiletti, Matrimonio, DPAC II 2186; Insadowski, Rzymskie prawo matżeńskie, s. 132-133; Ritzer, Le mariage dans les Églises chrétiennes, s. 77-79; zob. Augustinus, Sermo 9, 11, 18, PL 38, 88: „Ad hoc enim ducitur uxor: nam id etiam tabulae indicant ubi scribitur: «Liberorum procreandorum causa»”; Sermo 51, 13, 22, PL 38, 345: „Recitantur tabulae et recitantur in conspectu omnium attestantium et recitantur: «liberorum procreandorum causa»: et vocantur tabulae matrimoniales"; Sermones 37, 6, 7, PL 38, 225; 278, 9, 9, PL 38, 1272; Ennarratio in Ps. 80, 21, PL 37, 1045; De civitate Dei XIV 18; De nuptiis et concupiscentia I 4, 5; H. Marin, Le „, Tabulae matrimoniales” in S. Agostino, „Siculorum Gymnasium” 59 (1976) 307-321.

${ }^{11}$ Por. K. Ganszyniec, Kranz, PW XI 1588-1607; J. Schrijnen, La couronne nuptiale dans 
wszelkich ozdób togę, przepasana zawiązanym w węzeł Herkulesa paskiem i prostą długą tunikę oraz w krótki, osłaniający uczesaną na wzór westalek fryzurę i policzki, opadający na ramiona czerwono-złoty (flammeum) lub szafranowy (croceum) welon, razem z panem młodym, mając jeszcze często na czwartym palcu lewej ręki żelazne, proste, zaręczynowe obrączki na znak dozgonnej wierności ${ }^{12}$, byli koronowani przez ojców ${ }^{13}$, lub częściej przez kapłanów wieńcami z kwiatów ${ }^{14}$, którzy również udzielali specjalnego błogosławieństwa małżeńskiego ${ }^{15}$. Temu to ślubnemu koronowaniu nowożeńców Jan Chryzostom nadał jeszcze inne symboliczne znaczenie. Wieniec nałożony na głowę miał być według niego symbolem zwycięstwa ich czystości, którą zachowali aż do zawarcia małżeństwa ${ }^{16}$.

Złotousty nic nie wspomina o konieczności obecności przy tym akcie jakiegoś duchownego, czy nawet biskupa. Nie wydaje się więc, by zawarcie małżeństwa przez chrześcijan musiało być już wówczas na Wschodzie sankcjonowane przez osobę duchowną ${ }^{17}$. Możemy przypuszczać, że skoro w cza-

l'antiquité chrétienne, «Mélanges d'Archéologie et d'Histoire" 31 (1911) 309-319; A. von Salis, Die Brautkrone, "Rheinisches Museum" 73 (1920) 210-215; K. Baus, Der Kranz in Antike und Christentum, Bonn 1940 (Nachdruck 1965), 93-112 (Der Hochzeitskranz).

${ }^{12}$ Por. Plinius, Historia Naturalis XXXIII 12: „ferreus anulus isque sine gemma“; Tertullianus, Apologeticum 6, 4, CCL 1, 97: „Quem [digitum] sponsus oppignerasset pronubo anulo”; Isidorus, De ecclesiasticis officiis II 20, 8, CCL 113, 92: „Illud vero, quod imprimis anulus a sponso sponsae datur, fit hoc nimirum vel propter mutuae fidei signum, vel propter id magis, ut eodem pignore eorum corda iungantur. Unde et quarto digito anulus idem inseritur, quod eo vena quaedam, ut fertur, sanguinis ad cor usque perveniat”; tenże, Etymologiae XIX 32, 4, PL 82, 702: „Feminae non usae anulis, nisi quos virgini sponsus miserat"; F.J. Dölger, Anulus pronubus, ACh 5 (1936) 188-200; Insadowski, Rzymskie prawo matżeńskie a chrześcijaństwo, s. 36-37.

${ }^{13}$ Por. Gregorius Nazianzenus, Epistula 231, PG 37, 374BD, thum. J. Stahr, POK 15, 277-278: „Euopion najmilsza! Zatem wesele blisko - życie ma podstawę - ojców modły spełnione. A mnie tam nie ma, choć ja osobiście winienem tam być i modlić się z wami. Wszakżem ci to obiecał [...]. $\mathrm{O}$ to bym się dla was modlił i teraz się modlę. O wszystko inne wy miejcie staranie, ojciec niech pannę uwieńczy, jak sobie życzył. To bowiem, jeśli nawet jestem kiedy na weselu, postanowiłem, że do ojców należą wieńce, do mnie zaś modlitwy".

${ }^{14}$ Por. Ritzer, Le mariage dans les Églises chrétiennes, s. 135-137.

${ }^{15}$ Por. K. Stevenson, Nuptial blessing: a study of Christian marriage rites, London 1982; Ritzer, Le mariage dans les Églises chrétiennes, s. 134-135.

${ }^{16}$ Tylko te osoby, które zachowały czystość przedmałżeńską, mogły nosić wieńce, zaś te osoby, które jej nie zachowały nie miały prawa dostąpić takiego zaszczytu, por. In epistulam I ad Timotheum hom. 9, 2, PG 62, 546, tłum. T. Sinko: Św. Jan Złotousty, Homilie na listy pasterskie św. Pawła, Kraków 1948, 99-100: „Dlatego właśnie państwu młodym wkłada się na głowy wieńce, symbol zwycięstwa, że niezwyciężeni idą do małżeństwa i nie ulegli rozkoszy. Jeżeli zaś młodzieniec ogarnięty chęcią używania oddaje się nierządnicom, dlaczego jeszcze ma nosić na głowie wieniec, skoro został zwyciężonym"; zob. Ritzer, Formen, Riten und religiöses Brauchtum, s. 77-78.

17 A. Natali kategorycznie twierdzi, że to właśnie obecność przedstawiciela Kościoła, błogosławiącego związek małżeński, odróżniała tę ceremonię od pogańskiej, por. A. Natali, Mariages chrétiens à Antioche au IV siècle, w: Sociabilité, pouvoirs et société. Actes du Colloque (Rouen 24-26 novembre 1983), textes réunis par F. Thelamon, Rouen 1987, 111. 
sach Chryzostoma Kościół nie narzucał ceremonii ślubnej własnej formy, to tym samym obecność kapłana nie była wymagana. Była ona jak najbardziej wskazana i przez Kościół pożądana. Kościół jednak dostosował się do istniejącego zwyczaju zabraniając jedynie praktyk pogańskich. Złotousty nie pisze o takim obowiązku, nadmienia o nim jedynie w charakterze zachęty. Proponuje, by w przeddzień tak ważnej uroczystości, która niewątpliwie miała charakter tradycyjny, zapraszać do domu duchownych, aby ci modląc się nad szczęściem narzeczonych udzielali im błogosławieństwa ${ }^{18}$ i tym samym umacniali ich pożycie ${ }^{19}$. Obecność kapłanów przy zawieraniu małżeństwa porównuje do pobytu Chrystusa na weselu w Kanie Galilejskiej ${ }^{20}$. W Kanonach Ojców Greckich możemy odnaleźć informację, która potwierdza, że duchowni mogli być obecni przy akcie zawierania małżeństwa, ale kapłan mógł także odmówić udziału w tej ceremonii, jeśli uznałby ten akt za zagrożenie dla moralności chrześcijan ${ }^{21}$.

Nie posiadamy w tym czasie jeszcze żadnych informacji na temat istnienia jakichś ślubnych ceremonii odbywających się w kościele. Również ze znanego listu Grzegorza z Nazjanzu do Prokopiusza, w którym usprawiedliwia swoją

${ }^{18}$ Por. Joannes Chrysostomus, In illud: „Propter fornicationes” 3, PG 51, 211, thum. T. Krynicka (rękopis): „Skoro przywołujesz śpiewami demony, skoro szpetnymi słowami zadowalasz ich pożądanie, skoro wprowadzasz do siebie mimów, rozpustników i cały teatr, skoro wypełniasz dom nierządnicami, skoro sprawiasz, że cały rój demonów tam hula, czegóż dobrego spodziewasz się w przyszłości? Po cóż przyprowadzasz kapłanów, jeśli następnego dnia masz zamiar podobnych rzeczy dokonywać? Chcesz wykazać się hojnością przynoszącą zysk?”.

${ }^{19}$ Por. tenże, In Genesim hom. 48, 6. PG 54, 443C: „,należało kapłanów zaprosić oraz modlitwami i błogosławieństwami zgodę małżeństwa umocnić"; In Epistolam I ad Thessalonicenses hom. 10, 1, PG 62, 456.

${ }^{20}$ Por. tenże, In illud: „Propter fornicationes” 2, PG 51, 210; zob. De inani gloria 88, SCh 188, 194, tłum. W. Kania, BOK 19, 103: „Zaprośmy na wesele Chrystusa - godny jest bowiem tego oblubieniec. Zaprośmy Jego uczniów"; In Epistolam ad Colossenses hom. 12, 7, PG 62, 390, thum. J. Krykowski, „Roczniki Teologiczne Warszawsko-Praskie” 2 (2002) 58-59: „Kiedy zaś wyprawiasz wesele, nie krąż po domach, pożyczając lustra i szaty. Albowiem to, co się odbywa, nie jest dla ostentacji ani też nie prowadzisz córki na paradę. Rozweselając natomiast dom tym, co w nim jest, zwołaj sąsiadów, przyjaciół i krewnych. Tych, o których wiesz, że są mądrzy, tych zwołaj i zachęcaj, aby zadowolili się tym, co jest. Niech nie będzie obecny nikt spośród tych, którzy przychodzą z miejsca tańców. Jest to bowiem wydatek zbyteczny i niestosowny. Przede wszystkim zaproś Chrystusa. Wiesz, z jakiego powodu powinieneś Go zaprosić? «Kto uczynił coś dla jednego z tych najmniejszych, dla mnie to uczynił» (Mt 25, 45). Nie sądź, że jest rzeczą przykrą zapraszać ubogich ze względu na Chrystusa; jest rzeczą przykrą zapraszać nierządnice. Albowiem zapraszanie ubogich jest początkiem bogactwa, tamto zaś początkiem ruiny"; zob. też wyżej nota 7.

${ }^{21}$ Por. Canones Patrum Graecorum. Timotheus Alexandrinus can. 11, thum. S. Kalinkowski, ŹMT 49, 93: „Pytanie: Jeśli ktoś prosi duchownego o asystowanie przy zawieraniu małżeństwa, ten zaś wie, że związek taki byłby niegodziwy, na przykład z siostrzenicą albo z siostrą zmarłej żony, czy duchowny powinien zadośćuczynić prośbie i odprawić eucharystię? Odpowiedź: Sami stwierdziliście: «jeśli duchowny wie, że związek ten byłby niegodziwy»; jeśli zatem małżeństwo jest niegodziwe, duchowny nie może uczestniczyć w cudzym grzechu". 
nieobecność na weselu wydawanej przez niego krewniaczki Olimpiady, mimo iż było na nim wielu biskupów ${ }^{22}$, wynika, że nie jest jasne, czy kapłani odgrywali jakąś specjalną rolę $\mathrm{w}$ ceremonii zawarcia małżeństwa. Już wcześniej Ignacy z Antiochii w swoim Liście do Polikarpa napisał, że wskazane byłoby, aby akt zawarcia małżeństwa odbywał się w obecności biskupa i za jego zgodą, gdyż wtedy zawarty byłby wedle praw boskich ${ }^{23}$. Podobnie Tertulian, który potwierdzał fakt błogosławieństwa związku przez duchownego ${ }^{24}$ oraz podkreślał, że takie usankcjonowanie małżeństwa jest tym samym potwierdzone przez Boga ${ }^{25}$. Potem św. Augustyn poświadcza, że biskup podpisywał kontrakt małżeński na tabulae matrimoniales po jego publicznym odczyta$n^{n i{ }^{26}}$. Obecność kapłana podczas uroczystości zaślubin potwierdza także 54. kanon synodu w Laodycei we Frygii pod koniec IV wieku, gdzie czytamy:

„Kapłani oraz duchowni niższego stopnia uczestniczący w weselach lub przyjęciach nie powinni przyglądać się widowiskom, lecz przed występem aktorów winni się stamtąd oddalić”27.

Wielce prawdopodobne jest, że sami chrześcijanie zdawali sobie sprawę z tego, że związek powinna uświęcać obecność Chrystusa. Może o tym świad-

${ }^{22}$ Por. Gregorius Nazianzenus, Epistula 193, PG 37, 316-317, thum. J. Stahr, POK 15, 238: „Czuję twoje wyrzuty, chociaż milczysz. «Obchodzimy wesele» - rzekniesz może - «i to wesele złotej Olimpiady, tej twojej; obecne było grono biskupów, a ciebie nie było, zacności, alboś nie raczył alboś zaniedbał» [...] masz oto ode mnie weselny żart. Bo sercem i ochotą jestem wśród was i świętuję z wami i splatam wzajem prawice dwojga młodych, a potem obie z prawicą Bożą. Jak wszystko dobrze ci się wiedzie, tak godzi się, by i to małżeństwo dokonało się ku wszelkiemu dobru i według naszych wspólnych życzeń".

${ }^{23}$ Por. Ignatius Antiochenus, Epistula ad Polycarpum 5, 2, SCh 10, 176, tłum. A. Świderkówna, BOK 10, 141: „Godzi się, aby mężczyźni, którzy się żenią i kobiety, które wychodzą za mąż, łączyli się z wiedzą biskupa, aby małżeństwo było zawierane zgodnie z myślą Bożą, a nie zgodnie z pożądliwościami”.

${ }^{24}$ Por. Tertullianus, Ad uxorem II 6, 2, CCL 1, 391: „Ubi divina benedictio?”.

${ }^{25}$ Por. tamże II 9, 1, CCL 1, 393, thum. K. Obrycki, PSP 29, 164: „Skąd zaczerpniemy siły, by przedstawić szczęście takiego małżeństwa, które przez Kościół jest zawarte, przez ofiarę umocnione błogosławieństwem naznaczone, które aniołowie publicznie ogłaszają, w którym Ojciec [niebieski] ma upodobanie (felicitatem eius matrimonii, quod Ecclesia conciliat et confirmat oblatio et obsignat benedictio, angeli renuntiant, pater rato habet); zob. H. Crouzel, Deux textes de Tertullien concernant la procedure et les rites chrétiens du mariage, BLE 74 (1975) 5-13; K. Ritzer, Le mariage dans les Églises chrétiens, Paris 1970, 110-123; J. Moingt, Le mariage des chrétiens, w: Mariage et divorce, Paris 1974, 220-229.

${ }^{26}$ Por. Augustinus, Sermo 552, 4, PL 38, 1465: „Sufficiant vobis uxores vestrae, quia sufficere vos vultis uxoribus vestris. Non vis ab illa fiat aliquid praeter te, noli facere aliquid praeter ipsam [...]. Verum est: istis tabulis subscripsit episcopus: ancillae vestrae sunt uxores vestrae, domini estis uxorum vestrarum".

${ }^{27}$ Por. Concilium Laodicenum can. 54, ed. P.P. Joannou: Les canons des synodes particuliers, Fonti, fasc. IX, t. I/2, Grottaferrata - Roma 1962, 152. Nie znamy dokładnej daty, ani uczestników tego synodu, choć jego kanony znajdują się we wszystkich kolekcjach praw. 
czyć jedna z płaskorzeźb, na której jest on obecny podczas aktu koronacji żony (nałożenia jej na głowę wieńca $\mathrm{z}$ kwiatów) i połączenia dłoni małżonków ${ }^{28}$. $\mathrm{Na}$ niektórych monetach oraz medalionach, przedstawiających scenę dextrarum coniunctio, widoczna jest postać kobieca, przypominająca pronubę lub symbolizująca zgodę (concordia), która ma oznaczać wierność i jedność małżeńską aż do śmierci. Wizerunek ten pojawia się już na reliefach nagrobnych z okresu republiki i funkcjonuje aż do czasów wczesnochrześcijańskich ${ }^{29}$.

Po tak ważnym wydarzeniu reszta dnia upływała na świętowaniu, któremu towarzyszyła wystawna uczta weselna. Gromadzenie niezbędnych produktów odbywało się już dużo wcześniej. U rybaków oraz myśliwych zamawiano potrzebne na tę okoliczność pożywienie:

„ci, którzy przygotowując uroczystości weselne, gromadzą jedzenie złożone $\mathrm{z}$ różnorodnych potraw. Nie w dzień weselny, lecz na długo przedtem układa się z rybakami i ptasznikami, aby nie dać się zaskoczyć niedostatkiem czasu w zestawieniu spisu potraw"30.

Jan Chryzostom namawia do wstrzemięźliwości, do umiarkowania w jedzeniu i piciu. Apeluje też, by poprzez zapraszanie biednych na uroczystości weselne w ten sposób gościć na nich samego Chrystusa ${ }^{31}$. Ówczesne uczty nie wyróżniały się skromnością oraz umiarem, i podobnie jak dzisiejsze, wystawne przyjęcia, organizowane były z wielkim przepychem. Uroczystości weselne były rodzajem nieustającej konkurencji, wyznaczając pozycję społeczną danej rodziny. Osoby biedniejsze, w związku z mniejszymi możliwościami finansowymi, pokazywały swoją pozorną majętność przez pożyczanie różnorodnych, drogich sprzętów od swoich znajomych. Chryzostom nadmienia, jakoby ludność miała pożyczać m.in. lustra oraz drogie szaty. Jeśli ktoś miał mieszkanie niewielkich rozmiarów, wynajmował lub konstruował prowizoryczne miejsca zastępcze, by tam przez kilka dni przyjmować gości ${ }^{32}$. Należy pamiętać, ze

${ }^{28}$ Por. L. Dattrino, Il matrimonio nel pensiero di San Giovanni Crisostomo, Roma 2002, 50.

${ }^{29}$ Por. L. Reechmans, La 'dextrarum coniunctio'dans l'iconographie paléochrétienne, „Bulletin de l'Institut Historique Belge de Rome" 58 (1951) 23-24.

${ }^{30}$ Joannes Chrysostomus, Adversus Iudaeos oratio 4, 1, PG 48, 857, tłum. J. Iluk, ŹMT 41, 119.

${ }^{31}$ Por. tenże, In Epistolam ad Colossenses hom. 12, 7, PG 62, 390, thum. J. Krykowski, zob. wyżej nota 20.

${ }^{32}$ Por. tamże, tłum. J. Krykowski, s. 58-59: „Kiedy zaś wyprawiasz wesele, nie krąż po domach, pożyczając lustra i szaty. Albowiem to, co się odbywa, nie jest dla ostentacji ani też nie prowadzisz córki na paradę. Rozweselając natomiast dom tym, co w nim jest, zwołaj sąsiadów, przyjaciół i krewnych [...]. Niech nie będzie żadnego zgiełku, żadnego zamieszania. Niech zostanie wezwany oblubieniec, niech przyjmie pannę. Obiady i wieczerze niech będą pełne nie pijaństwa, lecz radości duchowej. Albowiem nieskończone będą bogactwa pochodzące z takiego małżeństwa, a zasoby życiowe będą zapewnione. Zobacz natomiast, ile zła pochodzi z wesel, które odbywają się obecnie (jeżeli w ogóle można nazywać je weselami, a nie zewnętrznymi obchodami). Zakończyły się święta zaślubin, a zarazem obawa i lęk, czy nie zniszczył się żaden z wypożyczonych przedmiotów, a na miejsce radości wchodzi zniechęcenie nie do zniesienia"; In epistulam ad Ephesios hom. 
ówczesne biesiady trwały do siedmiu dni i dopiero po tygodniu wszyscy się rozchodzili ${ }^{33}$.

Tak jak to zostało już wspomniane wcześniej, uroczystości rodzinne w domu panny młodej trwały do wieczora. Kiedy robiło się ciemno, kobiety i koleżanki panny młodej wraz z obecnymi gośćmi formowały orszak weselny, by towarzyszyć młodej mężatce przy przeprowadzce do domu narzeczonego. Ceremonia ta rozpoczynała się od porwania oblubienicy z domu rodzicielskiego: czyniła to pronuba zabierając ją z objęć matki i wręczając oblubieńcowi. Wydarzenie to, będące momentem konstytuowania się nowej rodziny, mogło być kojarzone ze sceną uprowadzenia ${ }^{34}$. Ten właśnie element ceremonii weselnej wzbudzał u Chryzostoma najwięcej wątpliwości i oburzenia, odnajdujemy w nim bowiem najwięcej reminiscencji obyczajowych związanych z kulturą pogańską. Ojciec panny młodej w dniu zaślubin wydawał wystawną ucztę, na której podawano $\mathrm{m}$. in. podpłomyki będące symbolem płodności. Po uczcie wieczornej pan młody na Wschodzie prowadził zazwyczaj młodą żonę do wozu zaprzęgniętego w muły, konie lub bawoły, na którym ona siadała obok swojego męża i rodziców. Za wozem szedł orszak weselny, któremu towarzyszyła wrzaskliwa muzyka instrumentalna, wynajęci aktorzy teatralni i mi-

20, 7, PG 62, 145-146, tłum. M. Jurek, BOK 19, 64: „Nigdy nie przystoi pozwalać na nieprzyzwoite tańce i piosenki. Wiem, iż może się to komuś wydawać śmieszne, że takie rzeczy nakazuję, jednakże jeśli mnie posłuchacie, gdy nadejdzie czas, przyniesie to wam pożytek. Wtedy poznacie korzyści. I okaże się, że były to zwyczaje pijanych mężczyzn i nieprawych dzieci. To zaś, do czego zachęcam jest cechą roztropności, umiłowania mądrości i godniejszego życia. Na co trzeba zwrócić uwagę? Wszystkie niestosowne piosenki, szatańskie i niegodne śpiewy, zbiegowiska bezwstydnych młodzieńców niszczą małżeństwo, i mają zły wpływ na młodą żonę. Zaraz bowiem będzie myśleć: «Jaki jest ten mąż! Nie prowadzi żadnego życia towarzyskiego, wprowadził mnie do domu dla rodzenia i wychowywania dzieci, dla pilnowania domu». Ale czy to może podobać się żonie? Przez dzień, dwa, później nie. Jeśli bowiem ktoś przed zawarciem małżeństwa nie stroni od grania fletów i od głośnych pieśni, z czasem może zacząć czynić lub mówić coś niegodnego. Gdy już oczyścisz małżeństwo z tego wszystkiego, staraj się je właściwie kształtować. Przez długi czas pielęgnuj skromność, a nie niszcz jej od razu".

${ }^{33}$ Por. tenże, Adversus ebriosos et resurrectione 5, PG 50, 441, tłum. T. Sinko: Św. Jan Złotousty, Dwadzieścia homilij i mów, Kraków 1947, 187-188: „Usuńmy więc wszędzie źródła grzechów! Dlatego właśnie korzystacie codziennie z nieustannej nauki; dlatego przez siedem dni z rzędu odprawiamy nabożeństwo i zastawiamy wam duchowy stół i pozwalamy wam karmić się słowem Bożym, ażeby was codziennie namaścić do zapasów i uzbroić przeciwko diabłu [...]. Zresztą to, co się tu odbywa, to także zaślubiny duchowe, a przy zaślubinach i weselu komnaty do siedmiu dni są otwarte dla gości. Dlatego i ja ustanowiłem wam prawo, ażebyście przez siedem dni stawiali się w świętych komnatach. Lecz tam po siedmiu dniach wszyscy się rozchodzą, a tu, jeśli chcesz, możesz zawsze stawiać się w świętym przybytku. I po ślubie świeckim, po pierwszym lub drugim miesiącu, oblubienica nie cieszy się już taką miłością oblubieńca; tu zaś jest inaczej. Im bardziej czas naprzód się posuwa, tym gorętsza jest miłość oblubieńca, tym szczersze uściski, tym bardziej duchowe pożycie, o ile jesteśmy trzeźwi".

${ }^{34}$ Por. Natali, Mariages chrétiens à Antioche au IV siècle, s. 113; P. Szczur, Problematyka spoteczna, s. 310. 
mowie oraz pochodnie, zapalane przez matki nowożeńców. Podobny obrzęd występował w kulturze rzymskiej, tam jednak formujący się pochód poprzedzał młodą parę, uczestnicy zaś orszaku nieśli często wrzeciono oraz kądziel. Na czele pochodu szedł chłopiec posiadający jeszcze ojca i matkę z gorejącą pochodnią, a za nim oblubienica trzymana za ręce przez dwóch innych chłopców. Następnie szedł nowożeniec z rodzicami i przyjaciółmi, a za nimi szedł tłum hałasujących ludzi z okrzykiem talassio, oraz innymi niecenzuralnymi zawołaniami (fescennini versus) ${ }^{35}$. Złotousty Kaznodzieja głosił, że nie po to ludzie zawierają związek, by być w centrum rozpusty oraz nierządu, a nawet nie po to, by rodzić dzieci, lecz po to, by żyć w czystości ${ }^{36}$. Uważał, że małżeństwo nie jest jakimś spektaklem, tylko wielką tajemnicą obrazującą Kościół i Chrystusa. Wielokrotnie wyrażał swój sprzeciw wobec nieobyczajnych zachowań, które miały miejsce w trakcie wesela, a zwłaszcza zapraszanie na nie mimów i aktorów teatralnych ${ }^{37}$. Jakie to obyczaje i ekscesy wywoływały tak wielkie oburzenie Złotoustego?

${ }^{35}$ Por. U.E. Paoli, Matrimonio, w: Enciclopedia Italiana XXII, 580-581; Insadowski, Rzymskie prawo matżeńskie, s. 138-139.

${ }^{36}$ Por. Joannes Chrysostomus, In illud: „Propter fornicationes unusquisque suam uxorem habeat” 2-3, PG 51, 210 i 212-213, tłum. T. Krynicka (rękopis): „Małżeństwo jest najskuteczniejszym lekiem na rozpustę. Nie znieważajmy go więc diabelskimi uroczystościami, lecz tak, jak uczynili nowożeńcy z Kany Galilejskiej, niech czynią ci, którzy dzisiaj się żenią, niech mają pośród siebie Chrystusa [...]. Małżeństwo bowiem zostało wprowadzone nie po to, abyśmy oddawali się swawoli i wszeteczeństwu, lecz abyśmy zachowali czystość. Posłuchajże, co mówi Paweł: «Z powodu rozpusty niechaj każdy ma sobie żonę i niechaj każda ma własnego męża» (1Kor 7, 2). Są bowiem dwa powody, dla których zostało wprowadzone małżeństwo - zachowanie czystości i rodzicielstwo, głównym jednak powodem jest zachowanie czystości. Po tym bowiem, jak wkroczyło pożądanie, pojawiło się też małżeństwo niszczące nieumiarkowanie i skłaniające nas do tego, abyśmy mieli jedną kobietę. Rodzicielstwo bowiem nie wynika z małżeństwa, lecz z owych słów Bożych: «Rośnijcie i mnóżcie się, i napełniajcie ziemię» (Rdz 1,28). Potwierdzają to ci, którzy żyją w małżeństwie, ale nie mają dzieci. Tak wiec główną przyczyną jest czystość, zwłaszcza teraz, kiedy rodzaj ludzki napełnił cały świat. Od początku bowiem było rzeczą pożądaną mieć dzieci, aby każdy pozostawił po sobie pamiątkę i ślad swojego życia [...]. Tak więc jeden jest powód ustanowienia małżeństwa, to jest abyśmy nie oddawali się rozpuście, w tym celu został wprowadzony ten lek".

${ }^{37}$ Por. In Epistolam ad Colossenses hom. 12, 4-5, PG 62, 387BC, tłum. S. Longosz, Widowiska teatralne zagrożeniem, s. 186-187: „Jest rzeczą wstrętną i nieprzyzwoitą wprowadzać do domu zniewieściałych mężczyzn, pantomimów i wszelką pychę szatańską. Małżeństwo jest węzłem, węzłem ustanowionym przez Boga, nierządnica zaś jego rozwiązaniem i zniesieniem [...]. Dlaczego więc te zabawy i takie potwory wprowadzasz? Powiedz, czego się spodziewasz od nich usłyszeć? Wstydzisz się to powiedzieć? Ty się wstydzisz, a ich zmuszasz do czynienia tego? [...] Wszystko winno być pełne umiarkowania i skromności, powagi i szlachetności, ja zaś teraz widzę coś przeciwnego, widzę tańczących jak wielbłądy i muły [...]. Dlaczego więc nierządnice na weselu? Gdy podczas godów weselnych należałoby je ze wstydu ukryć i zakopać, gdyż są zepsuciem i złamaniem małżeństwa, to my je publicznie prowadzimy na wesele [...]. Małżeństwo nie jest teatrem. Jest tajemnicą i typem wielkiej rzeczy, a jeżeli go nie szanujesz, to uszanuj to, co jest jego typem. «Jest to wielki sakrament, ja zaś mówię w Chrystusie i w Kościele» (Ef 5, 32). Jest ono typem Kościoła i Chrystusa, a ty nierządnice na nic wprowadzasz?”; In illud: „Propter fornicationes unusquisque 
Przede wszystkim ekscesy podczas wieczornej przeprowadzki do domu pana młodego. Analogicznie, jak miało to miejsce w kulturze helleńskiej cały przemarsz wspomnianego pochodu z nowożeńcami odbywał się przy zapalonych pochodniach, grających instrumentach muzycznych i wyzywających śpiewach. Orszakowi towarzyszyły obelżywe krzyki kierowane pod adresem młodych małżonków. Funkcjonowały nawet dość oryginalne i osobliwe konkursy polegające na wulgarnym krasomówstwie: zwycięzcami byli ci, którzy wypowiedzieli jak najwięcej uwłaczających słów, zarówno pod adresem panny, jak i pana młodego. Niewątpliwie dla Chryzostoma był to widok niebywale odrażający, który określał mianem „diabelskiej ceremonii” ${ }^{38}$, odprawianej na ulicy, a nawet obejmującej rynek. Korowód zachowywał się na tyle głośno i skandalicznie, iż zdarzało się, że w środku nocy byli budzeni mieszkańcy miasta. Do świętujących w ten sposób przyłączały się również osoby z marginesu społecznego, uciekinierzy i niewolnicy, dla których uroczystość ta była okazją do darmowej rozrywki, na której można było dobrze się zabawić i napić. Ogólna uciecha i zachowania obecnych na niej ludzi przybierały cechy zbiorowej rozwiązłości, w której przestawały obowiązywać jakiekolwiek bariery. Chryzostom ubolewa, że podczas tego rodzaju orgiastycznych zabaw wiele niewinnych dziewcząt i oblubienic bywało kalanych i obrażanych oraz uczo-

suam uxorem habeat” 2, PG 51, 211, tłum. T. Krynicka (rękopis): „Fletów, piszczałek, cymbałów, pijanych skoków i pozostałej zdrożności [dawniej na weselach] nie było. Niektórzy z nas natomiast dziś śpiewają tańcząc hymny do Afrodyty, opiewając w tym dniu wielką rozwiązłość, skażenie małżeństw, występne miłostki, niedozwolone związki i jeszcze wiele innych bezbożności i sromot, po upiciu się zaś i dokonaniu wszystkich tych nieprzyzwoitości odprowadzają wspólnie pannę młodą. Jakże możecie wymagać czystości od tej, którą od pierwszego dnia małżeństwa uczycie podobnego bezwstydu, na której oczach pozwalacie mówić i czynić podobne rzeczy, których nawet niewolnicy, jeśli są zacni, nie powinni słuchać? Tyle czasu poświęcił ojciec wraz z matką strzegąc czystości dziewicy, troszcząc się, aby tych słów ani nie mówiła, ani nie słyszała! Temu miały służyć osobne pokoje, przebywanie w przeznaczonej dla kobiet części domu, straże, drzwi, zamki. Kiedy wychodziła wieczorową porą czyniono wszystko, aby nikt z najbliższych nawet osób jej nie widział. A ty przyszedłeś i w jednym dniu to wszystko udaremniłeś, urządzając zaś ów niegodziwy pochód, sprawiłeś, że stała się bezwstydna i wlałeś w duszę panny młodej zepsute słowa. Czyż nie stąd właśnie biorą początek następujące później nieszczęścia? Czyż nie stąd pochodzą późniejsze zdrady i zazdrość? Czyż nie stąd bezdzietność, wdowieństwo, przedwczesne zgony rodziców? Skoro przywołujesz śpiewami demony, skoro szpetnymi słowami zadowalasz ich pożądanie, skoro wprowadzasz do siebie mimów, rozpustników i cały teatr, skoro wypełniasz dom nierządnicami, skoro sprawiasz, że cały rój demonów tam hula, czegóż dobrego spodziewasz się po nich w przyszłości?’”.

${ }^{38}$ In Genesim hom. 48, 6, PG 53, 443C, thum. S. Longosz (rękopis): „Dlaczego, odpowiedz, proszę, zaraz na początku małżeństwa pozwalasz uszy swej oblubienicy kalać tak brudnymi i wstrętnymi piosenkami i tak nieodpowiednim przepychem? Czy nie wiesz, że młodość sama przez się skłonna jest do złego? Dlaczego tajemnice godów weselnych publicznie zniesławiasz? Gdy należało to wszystko odrzucić i od początku uczyć dziewczynę skromności, zaprosić kapłanów, modlitwą i błogosławieństwem umocnić zgodę małżeńską, aby powiększała się miłość oblubieńca i umacniała się wstrzemięźliwość oblubienicy, a wszystko, co się wówczas dokonuje, zmierzało do tego, by uczynki cnoty wprowadzane były do nowego domu, to ty tak postępujesz?”. 
nych rozwiązłości i niewierności małżeńskiej. Wyróżniają się w tym szczególnie zapraszani ludzie teatru, których zadanie polegało na rozweselaniu gości, wymyślnych tańcach i niewybrednych żartach. Wskazywał jednak, że poprzez wprowadzanie do domów mimów, aktorów, ludzi zdeprawowanych oraz prostytutek, ów dom można porównać do teatru, po ich zaś występach, jakie oni prezentują, nie można oczekiwać niczego dobrego. Wskazywał też, że wiele nadużyć wynika z naśladowania scen rozgrywających się $\mathrm{w}$ teatrach publicznych. Bolał więc nad tym, że tego rodzaju weselne praktyki, były wówczas tolerowane, a nawet nazywane wiekowym zwyczajem, a on zwalczając je ośmiesza się i może być uważany za głupca i dziwaka. Godził się jednak na takie ośmieszanie samego siebie, byleby z tego wynikła moralna korzyść. Oto jedna z dłuższych jego wypowiedzi, ukazujących jego stosunek do ekscesów ostatniego etapu ówczesnych godów weselnych, podsumowujących powyższe uwagi:

„Należy uważać, że owe zwyczajowe praktyki wnoszą wiele obrazy, śmiechu i komedii. Wiem również, że przez to wielu będzie nas potępiać jako głupców i godnych śmiechu, lecz ścierpię to, że jestem wyśmiany, byleby tylko z tego wynikła jakaś korzyść [...]. Spójrz, co z nich wynika: nie tylko w ciągu dnia, ale i wieczór wielu pijanych mężczyzn, przesyconych i rozpalonych rozwiązłością, szykuje się by oglądać piękno dziewiczego oblicza. I nie tylko w domu, lecz także przez rynek spieszą na jej oglądanie, gdy późnym wieczorem prowadzą ją z pochodniami, aby przez wszystkich była oglądana, do niczego innego nie dążąc, żeby w końcu całą swą niewinność musiała stracić. I od niczego się tu nie powstrzymują, ale z obelżywymi słowami ją prowadzą, a to dla wielu stało się również prawem: zbiegowie, niezliczeni niegodziwcy, pijacy i straceńcy, wszystko ze swobodą wykrzykują, co tylko zechcą, czy to na nią, czy na oblubieńca, który ma z nią żyć; nic szlachetnego, lecz wszystko, co brudne i pełne nieprzyzwoitości. Czy oblubienica otrzyma przez to piękną naukę o czystości widząc i słysząc takie rzeczy? Pojawia sie nawet pewne diabelskie współzawodnictwo między tymi, którzy do takich rzeczy się wzajemnie zachęcają, by jedni drugich pokonać w obelżywych i ohydnych słowach, którymi obecnych plugawią. I ci stają się zwycięzcami, którzy ohydniejszymi i plugawszymi słowami rzucają. Wiem, że jestem może przykry, uciążliwy i natrętny, iż pozbawiam was pewnej przyjemności życia. I dlatego boleję, że rzeczy tak wstrętne uważane są przez was za przyjemność. Jak, pytam, odpowiedz mi - można być miłym, gdy się jest obsypywanym takimi obelgami, sprośnościami oraz przez wszystkich razem z oblubienicą zniesławiany? Jeżeliby ktoś z rynku ubliżył twojej małżonce, to poruszyłbyś wiele urzędów [by ją obronić] i nie uważasz, że to jest życiowe?; a gdy w obecności całego miasta tak ohydnie postępują z twoją przyszłą małżonką, to się cieszysz i chwalisz? Co to za głupota! a może powiesz, że jest to zwyczaj. I dlatego właśnie należy bardzo ubolewać, że diabeł rzecz tą 
nazwał zwyczajem. Skoro bowiem małżeństwo jest rzeczą szlachetną, która zachowuje i powiększa nasz rodzaj oraz jest przyczyną wielu dóbr, to Zły boleje i świadom jest tego, że owa broń jest ustanowiona przeciwko rozpuście, bo w przeciwnym razie wprowadziłby pełną rozpustę: w takich bowiem pochodach wiele dziewic jest zniesławianych. Choć nie zawsze, to jednak wystarczy demonowi, że owe słowa i owe bezwstydne piosenki śpiewają oraz oblubienicę i oblubieńca z pompą przez rynek prowadzą. A także, że dzieje się to wieczorem, aby zaś ciemności nie były zasłoną dla tego zła, niesie się wiele pochodni, które nie pozwalają zakryć tej ohydy. Cóż bowiem znaczy ów wielki tłum? Cóż pijaństwo? Cóż fujarki? Czy nie po to są one stosowane, aby nawet ci, którzy są w domu i w głębokim śnie pogrążeni dowiedzieli się o tych rzeczach, aby zbudzeni przez fujarki zrywali się ze snu i byli świadkami tej komedii. A cóż powiesz o samych piosenkach, które są pełne wszelkiej nieczystości, które opowiadają o naiwnych miłościach, nielegalnych związkach, rozbijaniu rodzin i niezliczonych tragediach oraz często wymieniają imiona kochanka i przyjaciela lub kochanki i przyjaciółki. Co więcej, występują w nich dziewice, które pozbywają się wszelkiego wstydu, i to niby dla uczczenia oblubienicy, owszem, raczej dla jej znieważenia; narażają swoje zdrowie i wśród młodzieńców nieprzyzwoicie się zachowując używając brudnych słów i głupich piosenek z szatańską melodią. A może zapytasz, skąd tyle cudzołóstwa? Skąd tyle rozpusty? Skąd rozbicie małżeństw? Chyba nie powiesz, że powodują to niewinne i szlachetne. Dlaczego zatem ośmieszasz mnie, gdy sam przede mną znasz to prawo. Jeśli bowiem dobre są owe zwyczaje, pozwól im również to czynić [...]. Gdy zaś teraz tańczy dziewica w tym wspólnym teatrze bezwstydnych młodzieńców, to pytam, czy nie jest podlejsza od nierządnicy? Jeśli zaś powiesz, że robią to głównie służące, to i tak nie przestanę cię oskarżać, bo i im nie wolno tego czynić"’39.

${ }^{39}$ In Epistolam I ad Corinthios hom. 12, 6, PG 61, 103-106, thum. S. Longosz (rękopis); por. In Epistolam ad Colossenses hom. 12, 6, PG 62, 386, thum. J. Krykowski, s. 51: „Co czynisz, człowieku? Ty nie wiesz, co czynisz. Bierzesz żonę dla umiarkowania i dla zrodzenia dzieci. Po cóż więc nierządnice? Mówi ktoś: aby była większa radość. Lecz czy nie jest to znakiem głupoty? Znieważasz pannę młodą, znieważasz zaproszone osoby. Albowiem jest to zniewaga, jeśli radują się z tych rzeczy. Jeżeli widzenie nieprzyzwoitych nierządnic wzbudza poczucie wzniosłości, to dlaczego nie sprowadzisz panny młodej, aby i ona je widziała? Jest rzeczą całkowicie nieodpowiednią i wstydliwą sprowadzać do domu zniewieściałych mężczyzn oraz tancerzy i całą tę szatańską pompę. «Wspomnijcie moje więzy» - mówi. Więzami są zaślubiny, więzami ustanowionymi przez Boga: rozwiązłość i rozpasanie są ich nierządnicą. Jest dopuszczalne rozweselanie zaślubin za pomocą innych rzeczy, na przykład zastawionych stołów oraz strojów. Ja oczywiście tego nie usuwam, aby nic wydawało się, że jestem zbyt surowy; nie usuwam tego, chociaż Rebece wystarczył zwykły strój. Jest dopuszczalne radowanie się ze strojów, z obecności godnych szacunku mężczyzn i godnych szacunku kobiet. Dlaczego więc wprowadzasz te przewrotne radości, dlaczego te monstra? Powiedz mi, co od nich słyszysz? Czy wstydzisz się, gdy to mówią? Ty się wstydzisz, lecz zmuszasz ich, aby to czynili. Jeśli jest to rzeczą dobrą, to dlaczego nie czynisz tego także ty? Jeżeli zaś jest to 
Chryzostom uważał, że również taniec jest tożsamy z obrzędami pogańskimi, natomiast chrześcijan powinien cechować umiar, porządek i skromnośćc ${ }^{40}$. Taniec był także przedmiotem dyskusji uczestników wspomnianego już synodu w Laodycei, na którym to stwierdzono:

„Chrześcijanie, którzy uczestniczą w przyjęciach weselnych, nie powinni skakać ani tańczyć, lecz z powagą spożyć obiad lub inny posiłek, tak jak to przystoi chrześcijanom" ${ }^{\prime 4}$.

Chryzostom nie pochwalał też wystawności w urządzanych ceremoniach, gdyż wiązało się to dość pokaźnymi wydatkami, którymi zresztą rodzice niekiedy się przechwalali ${ }^{42}$. Dla Złotoustego takie zwyczajowe praktyki weselne były niedopuszczalne i bardzo niebezpieczne, gdyż panna młoda oglądając i uczestnicząc $w$ takich ekscesach mogłaby wzniecić w sobie nie tylko chęć obserwowania niegodnych postępków, ale i wcielania ich w swoje własne życie. Miał on na uwadze przede wszystkim moralność młodej żony, która dotąd pilnie strzeżona przez rodziców, z dala od gorszących scen, poprzez słuchanie wyuzdanych piosenek i prowokacyjnych tańców mogła zostać zgorszona i wprawiona w zakłopotanie. Chryzostom pyta więc wielokrotnie męża, dlaczego ten pozwala, by w takie święto panna młoda wysłuchiwała obelżywych pieśni i wierszy o lubieżnej treści, skazując ją tym samym na zepsucie.

Podsumowując ten jakże barwny i dość osobliwy opis ceremonii zawarcia małżeństwa nie sposób nie zwrócić uwagi na powtarzające się apele Złotoustego do mieszkańców Antiochii, by ci zaprzestali tak wystawnego i sztucznego zachowania, w którym nastrój i teatralna oprawa uroczystości była niebezpiecznie zbliżona do wyuzdanych bachanaliów. Kaznodzieja apelował także do rodziców i młodego małżonka, aby przez organizację takich imprez, przepełnionych kontrowersyjnymi moralnie obyczajami, mieli na uwadze czystość dopiero co poślubionej kobiety. Żaden z argumentów wysu-

nikczemne, to dlaczego zmuszasz do tego innych?"; zob. Dmitruk, Obyczaje weselne i pogrzebowe chrześcijan, s. 264-275.

${ }^{40}$ Por. In Epistolam ad Colossenses hom. 12, 4, PG 62, 386B: „Czy gdy panna młoda tańczy, nie wstyd jej przed koleżanką? Trzeba, aby była godniejsza i poważniejsza niż tamta: wyszła bowiem od ręki , a nie z palestry. Dlatego bowiem w ogóle nie należy, aby dziewica pokazywała się na weselu [...]. Jeżeli więc - powie ktoś - nie tańczą ani panny, ani te, które wyszły za mąż, to kto będzie tańczył? Są tańce w misteriach Greków, w naszych zaś cisza i dostojna powaga, przyzwoitość i skromność. Dokonuje się bowiem wielkie misterium: precz z nierządnicami, precz z profanami”.

${ }^{41}$ Concilium Laodicenum can. 53, ed. P.P. Joannou, s. 151.

${ }^{42}$ Por. In Genesim hom. 65, 1, PG 54, 482, thum. S. Longosz, Widowiska teatralne zagrożeniem, s. 186: „Widziałeś, z jakim dostojeństwem odprawiano kiedyś wesele (Rdz 29, 20-23). Posłuchajcie wy, którzy podziwiacie diabelski przepych i zaraz na początku bezcześcicie godność małżeństwa. Czy były wtedy aulosy? Czy były wtedy cymbały? Czy były wtedy diabelskie tańce? Powiedz mi, dlaczego zaraz na początku wprowadzasz do swego domu tak wielkie błoto i wzywasz aktorów ze sceny i orchestry, aby z wielkimi wydatkami bezcześcić czystość oblubienicy i bezwstydniejszym czynić oblubieńca?". 
wanych przez Antiocheńczyka nie przemawiał jednak do ówczesnej ludności. Być może osoby, którym przyszło słuchać mów Chryzostoma, uważały, że jeśli cała ceremonia nie będzie przygotowana w huczny sposób, to dopiero co zawarte małżeństwo będzie nieważne ${ }^{43}$. Wystawne i huczne uczty od wieków były integralnym elementem związanym $\mathrm{z}$ uroczystością zawarcia małżeństwa. Kościół nie był w stanie złamać pradawnych konwencji. Na wprowadzenie własnych ceremonii było jeszcze za wcześnie.

\section{LES CÉRÉMONIE DU MARRIAGE EN RÉCIT DE SAINT JEAN CHRYSOSTOME}

\section{(Résumé)}

Dans cet article à partir des documents de Jean Chrysostome, on expose des étapes particuliers qui convienent avec la cérémonie du marriage. En analysant des divertissement décrits par Jean Chrysostome, on peut classer cette solennité en quelques étapes: 1. Le premier d'eux se commencaient le matin. Alors, à la maison de la jeune mariée la fiancée était rendue à son future mari. Cette tradition s'apellait exdosis; 2 . Ensiute, c'était le repas de noce très fasteux qui se passait; 3 . Le soir, le convoi de noce se réunissait et il guidait le jeune couple à la maison du nouveau marié. La fête pompeuse se finissait à la maisson du mari, décorée des guirlandes. Le mari prenait sa femme et il la menait à son lit. De ce moment-là, les jeunes mariés se commancaient leur vie commune et ils devaient oublier tous leurs patenaires précédents.

\footnotetext{
${ }^{43}$ Por. Dmitruk, Obyczaje weselne i pogrzebowe chrześcijan, s. 272.
} 


\section{ANEKS}

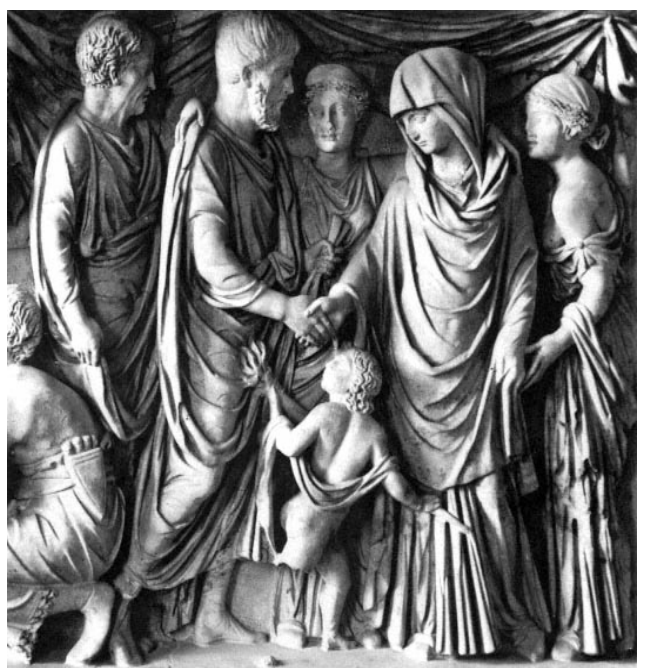

Il. 1. Fragment rzymskiego sarkofagu z 2. połowy II wieku ze sceną dextrarum coniunctio (między narzeczonymi postać Concordii). Mantua, Palazzo Ducale. Zdjęcie ze zbiorów: Alinari/Art Resource, New York (www.escholarship.org)

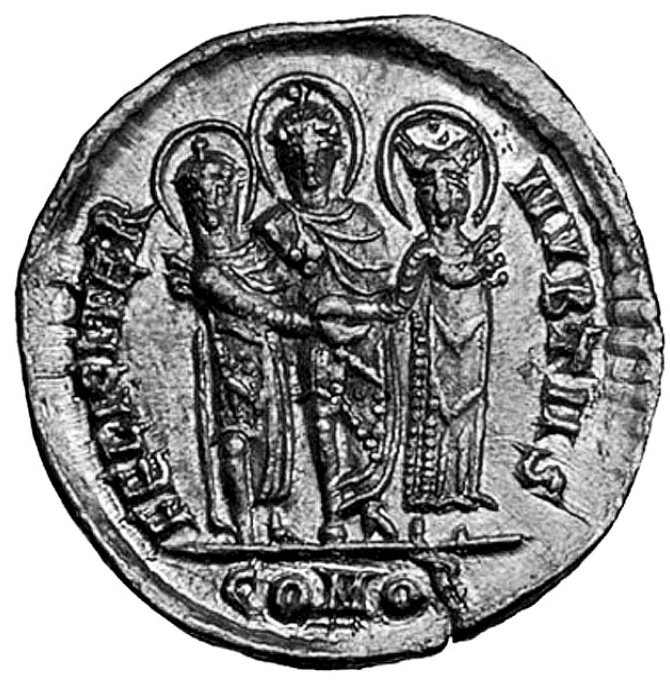

Il. 2. Rewers solida Teodozjusza II przedstawiający scenę dextrarum coniunctio (Walentynian III i Licynia Eudoksja w strojach ślubnych. Pośrodku ojciec panny młodej - Teodozjusz II). Zdjęcie ze zbiorów: http://en.wikipedia.org/wiki/Theodosius_II. 
